\title{
Haematological and Biochemical Alterations of Broiler Chicken Affected Naturally with Colibacillosis
}

\author{
Umar Amin*, S. A. Kamil, B. M. Wani, Saim Qureshi, S. A. Shah, \\ Tanveer Ahmad Dar, S. Adil and M. S. Mir
}

\author{
Division of Veterinary Pathology, Faculty of Veterinary Sciences and Animal Husbandry, \\ Shuhama, SKUAST-K, Kashmir, India \\ *Corresponding author
}

\begin{abstract}
A B S T R A C T
The present study was aimed to study the haematological and biochemical alterations of naturally occurring colibacillosis in broiler chickens. The haematological parameters studied were haemoglobin, haematocrit, TEC, MCV, MCH, MCHC, MPV, platelet crit, RDW, thrombocytes, TLC, heterophils, lymphocytes, monocytes, eosinophils and basophils. All these parameters in chicken affected with colibacillosis were comparable to noninfected chicken and within normal range. However, the serum biochemistry revealed marked alteration in liver function tests (AST and ALT), total protein, albumen and globulin in infected birds with values of $97.364 \pm 3.958 \mathrm{U} / \mathrm{L}, 85.093 \pm 1.557 \mathrm{U} / \mathrm{L}, 5.431 \pm 0.042 \mathrm{~g} / \mathrm{dL}, 2.420 \pm$ $0.026 \mathrm{~g} / \mathrm{dL}$, and $3.011 \pm 0.040 \mathrm{~g} / \mathrm{dL}$ respectively compared to non-infected chicken.
\end{abstract}

Keywords

Biochemistry, Broiler chicken, Colibacillosis, Haematology

Article Info

Accepted:

18 May 2020

Available Online:

10 June 2020

\section{Introduction}

The scenario of poultry diseases has also changed with emerging and re-emerging disease flaring up, thus imposing threat to the poultry industry. Among poultry diseases, which cause huge economic loss in terms of mortality and condemnation of carcasses at slaughter houses, avian colibacillosis caused by Escherichia coli, is considered as one of the major and principal causes of morbidity and mortality either as primary pathogen or as a secondary pathogen (LutfulKabir, 2010). Timothy et al., 2008 envisaged that at least $30 \%$ of the commercial flocks in U.S, at any point in time are affected by colibacillosis

Escherichia coli is commonly found as a commensal in alimentary tract of healthy birds and animals. Usually $10-15 \%$ of intestinal Escherichia coli are Avian Pathogenic Escherichia coli (APEC) possessing various virulence factors (Barnes et al., 2003). However, infection flares up 
when bird's defence mechanism is compromised by various factors such as bad management (Goswami et al., 2004), concurrent infections and immunosuppression.

Natural outbreak of colibacillosis in young chicken have been reported but concurrent course of illness among chicks of different age groups is quite intriguing, especially in view of multiplicity of different serogroups having different virulence capacity. APEC causes significant morbidity and mortality which attributes to multimillion-dollar losses for all facets of world's poultry industry (Barnes, 2008). However, there is no report on association of Escherichia coli serogroups with varied pathology seen in natural cases of colibacillosis.

Many studies have been carried out worldwide as well as in India on various aspects of pathology of colibacillosis. However, there seems to be no report on hemato-biochemical changes associated with different serotypes of E.coli under natural conditions especially in Jammu and Kashmir State with different agro-climatic conditions. Hence this study was carried out to study the hemato-biochemical alteration in E.coli affected birds.

\section{Materials and Methods}

The study was carried out in division of veterinary pathology, Shuhama, J and K. The outbreaks suspected for Escherichia coli in broiler chicken were identified based on the history, clinical signs and lesions, after following a thorough post mortem examination of birds. Blood from morbid birds which showed typical clinical signs of colibacillosis was collected for haematological and serological screening. Blood from apparently normal birds from normal flocks with no history / symptoms was also collected for haematological examination for comparison.

Five birds from each outbreak showing typical signs of colibacillosis were randomly selected for blood collection. Blood was drawn either from wing vein or by direct cardiac puncture. $1 \mathrm{ml}$ blood was transferred to vials containing EDTA for haematological estimation and $2 \mathrm{ml}$ of blood was transferred to sterilized tubes and slants were prepared for collection of serum for biochemical estimation. Same procedure was carried out for the birds which did not showed any apparent clinical signs/ lesions. Haematological studies included estimation of haemoglobin $(\mathrm{Hb})$, Total erythrocyte count (TEC), Total leucocyte count (TLC), Differential leucocyte count (DLC) using MS4 automatic haem-analyser (MELT, Schloesing Laboratories, France).

For determination of biochemical parameters serum samples were collected and kept at $40^{\circ} \mathrm{C}$. The samples were analysed for Total protein, Albumin, Globulin, AST and ALT by using routine diagnostic kits and semiautomated clinical chemistry analyzer (SFRI-BSA 3000, Lieu dit Berbanton, France). Protein estimation was done by Biuret method (Tietz, N. W. 1986), albumin by BCG method (Webster, D. 1974), AST and ALT by modified IFCC method (Thomas, L. 1998).

All the data generated in the study was analysed using SPSS software as per Snedecor \& Cochran, (1994).

\section{Results and Discussion}

The results of hematological alterations have been presented in Table 1 . The overall mean haemoglobin concentration in Escherichia coli infected chicken $(10.197 \pm 0.309 \mathrm{~g} / \mathrm{dL})$ was comparable with non infected chicken 
$(9.707 \pm 0.169 \mathrm{~g} / \mathrm{dL})$. There was significant increase in mean haemoglobin values in Escherichia coli infected birds of 15-21 $(10.820 \pm 0.752 \mathrm{~g} / \mathrm{dL})$ days age when compared with age matched non infected birds $(9.270 \pm 0.327 \mathrm{~g} / \mathrm{dL})$. The overall mean HCT values in Escherichia coli infected chicken $(31.043 \pm 1.075 \%)$ were compared with non infected chicken $(32.883 \pm 0.774$ $\%)$. The mean HCT values between age groups within the infected group did not did not vary significantly. Also there was no significant change in mean values of HCT in Escherichia coli infected birds when compared with age matched non infected birds. There was a slight increase in mean $\mathrm{Hb}$ value where as HCT values in Escherichia coli infected birds were comparable to non infected age matched groups. However, Jalil and Das, (2001) reported decrease in mean $\mathrm{Hb}$ values after in chicks infected with Escherichia coli. The discrepancy may be attributed to the differences in the overall model of the study and extreme variability in the clinical nature of the disease under natural conditions.

The overall mean Total Erythrocyte Count (TEC) values in Escherichia coli infected chicken $3.038 \pm 0.101\left(10^{6} / \mu \mathrm{L}\right)$ were compared with non infected chicken $3.264 \pm$ $0.083\left(10^{6} / \mu \mathrm{L}\right)$. The overall mean Mean Corpuscular Volume (MCV) values in Escherichia coli infected chicken (102.510 $\pm 1.145 \mathrm{fL}$ ) were compared with non infected chicken $(103.113 \pm 4.044 \mathrm{fL})$. The mean values of Mean Corpuscular Haemoglobin $(\mathrm{MCH})$ in Escherichia coli infected chicken $(34.316 \pm 1.367 \mathrm{pg})$ were compared with non infected chicken $(29.724 \pm 0.507 \mathrm{pg})$. The mean MCHC values between age groups within the infected group did not varied significantly. No significant difference in mean TEC, MCV, MCH, MCHC were observed in Escherichia coli infected chicken as compared with age matched values of non- infected groups. The results were in concurrence with the reports of Nandanwar $e t$ al., (1999), Jalil and Das, (2001) and Gangane et al., (2006) who reported no change in $\mathrm{MCV}, \mathrm{MCH}, \mathrm{MCHC}$ values in E.coli infected groups. However, results were in contrary to reports by Christie and Haliday who reported fall in TEC and Gangane et al., (2006) who reported a significant decrease in MCHC values in Escherichia coli infected birds.

The overall mean Mean Platelet Volume (MPV) values in Escherichia coli infected chicken $8.207 \pm 0.121 \quad\left(10^{3} / \mu \mathrm{L}\right) \quad$ were compared with non infected chicken $7.837 \pm$ $0.143\left(10^{3} / \mu \mathrm{L}\right)$. The overall mean Plateletcrit (PCT) values in Escherichia coli infected chicken $0.027 \pm 0.002(\%)$ were compared with non infected chicken $0.026 \pm 0.002(\%)$. The overall mean Red Cell Distribution Width (RDW) values in Escherichia coli infected chicken $(11.557 \pm 1.108 \%)$ were compared with non infected chicken $(9.313 \pm$ $0.273 \%$ ). The overall mean Thrombocyte (THR) values in Escherichia coli infected chicken $(92.200 \pm 1.679)$ were compared with non infected chicken $(27.967 \pm 0.970)$. Nandanwar et al., (1999) also reported no significant change in values of MPV, RDW and THR in Escherichia coli infected birds which were in concurrence with the observations recorded in present study.

The overall mean of total leucocyte count in infected chickens $40.800 \pm 1.125\left(10^{3} / \mu \mathrm{L}\right)$ was comparable with non infected chickens $26.497 \pm 0.620\left(10^{3} / \mu \mathrm{L}\right)$. The mean WBC count values of infected and non infected broiler chickens of different age groups ranged from $39.511 \pm 1.877\left(10^{3} / \mu \mathrm{L}\right)$ to $42.321 \pm 1.520\left(10^{3} / \mu \mathrm{L}\right)$ and $25.480 \pm 0.892$ $\left(10^{3} / \mu \mathrm{L}\right) \quad$ to $27.650 \pm 1.126\left(10^{3} / \mu \mathrm{L}\right)$ respectively. The mean WBC values between age groups within the infected group did not differ significantly. Also there was no significant change in mean values of WBC in 
Escherichia coli infected birds when compared with age matched non infected birds. The mean valves of leucocytes in the present study were significantly increased in Escherichia coli infected birds when compared with age matched birds of noninfected group. The leucocytosis is generally observed in septicaemia (Jain-NC-1986).

The mean values of heterophil count at different age groups are given in Table 3 . The overall mean heterophil count in Escherichia coli infected chicken $(59.834 \pm 2.026 \%)$ was comparable with non infected birds (33.100 \pm $0.042 \%)$. A significant increase in mean values was seen in infected group at $22-28$ days old birds when compared with the birds of same group. Also there was a significant increase in mean heterophil values in Escherichia coli infected birds when compared with age matched non infected birds. The overall average values of lymphocytes in infected chickens (17.760 \pm $1.140 \%)$ were compared with non infected chickens $(54.267 \pm 0.764 \%)$. The values of lymphocyte count between age groups within the infected group varied significantly and were lower in 15-21 days of age when compared with other age groups. The mean heterophil count was significantly increased with concurrent decrease in mean values of lymphocytes in Escherichia coli infected birds when compared with non-infected birds at various age groups. The increase in heterophil number occured due to recruitment of these cells as they are the first line defense against bacterial infections (Jain-NC-1986). The decrease in lymphocyte count may be attributed to immunosuppression. The results were in concurrence with observations of Gangane et al., (2006).

The overall mean monocyte count in Escherichia coli infected birds $(7.117 \pm 0.486$ $\%$ ) was comparable with non infected chicken $(8.733 \pm 0.151 \%)$. The mean values of monocyte count between age groups within the infected group varied significantly and were lower in 15-21 days of age when compared with other age groups. The overall mean eosinophil count in infected birds $(12.346 \pm 1.260 \%)$ was comparable with non infected birds $(3.900 \pm 0.260 \%)$.

The mean values of eosinophil count between age groups within the infected group varied significantly and were higher in 8-14 days of age when compared with other age groups. The overall mean basophil values in Escherichia coli infected chicken $(0.353 \pm$ $0.048 \%)$ were compared with non infected chicken $(0.320 \pm 0.028 \%)$. The mean values between age groups within the infected group did not vary differ significantly. The mean values of monocytes were significantly decreased and those of eosinophils were significantly increased in Escherichia coli infected birds when compared age matched birds of non-infected group.

The results of hematological alterations have been presented in Table 2. The overall mean AST value in Escherichia coli infected chicken (97.364 $\pm 3.958 \quad \mathrm{U} / \mathrm{L})$ was significantly higher when compared with non infected chicken $(56.931 \pm 0.800 \mathrm{U} / \mathrm{L})$. The values of AST between age groups within the infected group varied significantly and were higher in 15-21 days of age when compared with other age groups.

The overall mean ALT values in Escherichia coli infected chicken $(85.093 \pm 1.557 \mathrm{U} / \mathrm{L})$ were significantly higher when compared with non infected chicken $(65.083 \pm 0.663$ $\mathrm{U} / \mathrm{L})$. The values of ALT between age groups within the infected group did not vary. The mean values of AST and ALT were significantly increased in infected birds when compared with age matched birds of noninfected group. 
Table.1 Haematological alterations in chicken spontaneously affected with colibacillosis (Mean \pm SE)

\begin{tabular}{|c|c|c|c|c|c|c|c|c|c|}
\hline \multirow{2}{*}{$\begin{array}{l}\text { Parameters } \\
\text { Haemoglobin (g/dL) }\end{array}$} & \multirow{2}{*}{$\begin{array}{l}\text { Group } \\
\text { E. coli infected }\end{array}$} & \multicolumn{2}{|l|}{ 8-14 days } & \multicolumn{2}{|l|}{ 15-21 days } & \multicolumn{2}{|l|}{ 22-28 days } & \multicolumn{2}{|l|}{ Total } \\
\hline & & $9.890 \pm$ & $0.483^{\mathrm{aA}}$ & $10.820 \pm$ & $0.752^{\mathrm{aA}}$ & $9.880 \pm$ & $0.241^{\mathrm{aA}}$ & $10.197 \pm$ & 0.309 \\
\hline & Non-infected & $10.460 \pm$ & $0.212^{\mathrm{aA}}$ & $9.270 \pm$ & $0.327^{\mathrm{aB}}$ & $9.390 \pm$ & $0.173^{\mathrm{aA}}$ & $9.707 \pm$ & 0.169 \\
\hline \multirow[t]{2}{*}{ Haematocrit(\%) } & E. coli infected & $28.560 \pm$ & $1.162^{\mathrm{aA}}$ & $33.460 \pm$ & $2.163^{\mathrm{aA}}$ & $31.110 \pm$ & $1.950^{\mathrm{aA}}$ & $31.043 \pm$ & 1.075 \\
\hline & Non-infected & $32.590 \pm$ & $1.276^{\mathrm{aA}}$ & $32.850 \pm$ & $1.513^{\mathrm{aA}}$ & $33.210 \pm$ & $1.359^{\mathrm{aA}}$ & $32.883 \pm$ & 0.774 \\
\hline \multirow[t]{2}{*}{$\operatorname{TEC}(10 \% / \mu \mathrm{L})$} & E. coli infected & $2.929 \pm$ & $0.131^{\mathrm{aA}}$ & $3.248 \pm$ & $0.194^{\mathrm{aA}}$ & $2.936 \pm$ & $0.193^{\mathrm{aA}}$ & $3.038 \pm$ & 0.101 \\
\hline & Non-infected & $3.156 \pm$ & $0.131^{\mathrm{aA}}$ & $3.348 \pm$ & $0.176^{\mathrm{aA}}$ & $3.288 \pm$ & $0.129^{\mathrm{aA}}$ & $3.264 \pm$ & 0.083 \\
\hline \multirow[t]{2}{*}{ MCV(fL) } & E. coli infected & $97.880 \pm$ & $1.317^{\mathrm{aA}}$ & $102.930 \pm$ & $2.060^{\mathrm{aA}}$ & $106.720 \pm$ & $1.524^{\mathrm{aA}}$ & $102.510 \pm$ & 1.145 \\
\hline & Non-infected & $104.719 \pm$ & $5.699^{\mathrm{aA}}$ & $102.209 \pm$ & $9.567^{\mathrm{aA}}$ & $102.410 \pm$ & $5.800^{\mathrm{aA}}$ & $103.113 \pm$ & 4.044 \\
\hline \multirow[t]{2}{*}{ MCH (pg) } & E. coli infected & $34.060 \pm$ & $1.613^{\mathrm{aA}}$ & $33.440 \pm$ & $1.682^{\mathrm{aA}}$ & $35.447 \pm$ & $3.520^{\mathrm{aA}}$ & $34.316 \pm$ & 1.367 \\
\hline & Non-infected & $32.352 \pm$ & $0.835^{\mathrm{aA}}$ & $28.365 \pm$ & $0.467^{\mathrm{aA}}$ & $28.508 \pm$ & $0.654^{\mathrm{aA}}$ & $29.742 \pm$ & 0.507 \\
\hline \multirow[t]{2}{*}{$\operatorname{MCHC}(\mathrm{g} / \mathrm{dL})$} & E. coli infected & $34.770 \pm$ & $1.584^{\mathrm{aA}}$ & $32.460 \pm$ & $1.358^{\mathrm{aA}}$ & $32.825 \pm$ & $2.817^{\mathrm{aA}}$ & $33.352 \pm$ & 1.143 \\
\hline & Non-infected & $33.594 \pm$ & $1.411^{\mathrm{aA}}$ & $28.797 \pm$ & $2.492^{\mathrm{aA}}$ & $28.939 \pm$ & $1.190^{\mathrm{aA}}$ & $30.443 \pm$ & 1.080 \\
\hline \multirow[t]{2}{*}{$\operatorname{MPV}\left(10^{3} / \mu \mathrm{L}\right)$} & E. coli infected & $8.330 \pm$ & $0.104^{\mathrm{aA}}$ & $8.430 \pm$ & $0.165^{\mathrm{aA}}$ & $7.860 \pm$ & $0.289^{\mathrm{aA}}$ & $8.207 \pm$ & 0.121 \\
\hline & Non-infected & $7.850 \pm$ & $0.252^{\mathrm{aA}}$ & $8.040 \pm$ & $0.267^{\mathrm{aA}}$ & $7.620 \pm$ & $0.232^{\mathrm{aA}}$ & $7.837 \pm$ & 0.143 \\
\hline \multirow[t]{2}{*}{ PCT $(\%)$} & E. coli infected & $0.034 \pm$ & $0.003^{\mathrm{aA}}$ & $0.026 \pm$ & $0.003^{\mathrm{aA}}$ & $0.021 \pm$ & $0.003^{\mathrm{aA}}$ & $0.027 \pm$ & 0.002 \\
\hline & Non-infected & $0.025 \pm$ & $0.004^{\mathrm{aA}}$ & $0.026 \pm$ & $0.004^{\mathrm{aA}}$ & $0.027 \pm$ & $0.005^{\mathrm{aA}}$ & $0.026 \pm$ & 0.002 \\
\hline \multirow[t]{2}{*}{ RDW (\%) } & E. coli infected & $12.780 \pm$ & $0.854^{\mathrm{aA}}$ & $9.990 \pm$ & $0.681^{\mathrm{aA}}$ & $11.900 \pm$ & $3.198^{\mathrm{aA}}$ & $11.557 \pm$ & 1.108 \\
\hline & Non-infected & $9.350 \pm$ & $0.545^{\mathrm{aA}}$ & $8.860 \pm$ & $0.367^{\mathrm{aA}}$ & $9.730 \pm$ & $0.494^{\mathrm{aA}}$ & $9.313 \pm$ & 0.273 \\
\hline \multirow[t]{2}{*}{ Thrombocytes } & E. coli infected & $33.200 \pm$ & $0.786^{\mathrm{aA}}$ & $28.600 \pm$ & $4.212^{\mathrm{aA}}$ & $25.800 \pm$ & $2.407^{\mathrm{aA}}$ & $29.200 \pm$ & 1.679 \\
\hline & Non-infected & $26.500 \pm$ & $1.003^{\mathrm{aA}}$ & $30.100 \pm$ & $2.168^{\mathrm{aA}}$ & $27.300 \pm$ & $1.613^{\mathrm{aA}}$ & $27.967 \pm$ & 0.970 \\
\hline \multirow[t]{2}{*}{ TLC $\left(10^{3} / \mu \mathrm{L}\right)$} & E. coli infected & $39.511 \pm$ & $1.877^{\mathrm{aA}}$ & $40.576 \pm$ & $2.825^{\mathrm{aA}}$ & $42.312 \pm$ & $1.520^{\mathrm{aA}}$ & $40.800 \pm$ & 1.215 \\
\hline & Non-infected & $27.650 \pm$ & $1.126^{\mathrm{aB}}$ & $26.360 \pm$ & $1.178^{\mathrm{aB}}$ & $25.480 \pm$ & $0.892^{\mathrm{aB}}$ & $26.497 \pm$ & 0.620 \\
\hline \multirow[t]{2}{*}{ Lymphocytes (\%) } & E. coli infected & $20.720 \pm$ & $0.771^{\mathrm{aA}}$ & $14.200 \pm$ & $2.992^{\mathrm{bA}}$ & $18.005 \pm$ & $1.315^{\mathrm{bA}}$ & $17.760 \pm$ & 1.140 \\
\hline & Non-infected & $53.400 \pm$ & $0.991^{\mathrm{aB}}$ & $55.600 \pm$ & $1.222^{\mathrm{aB}}$ & $53.800 \pm$ & $1.611^{\mathrm{aB}}$ & $54.267 \pm$ & 0.746 \\
\hline \multirow[t]{2}{*}{ Monocytes (\%) } & E. coli infected & $8.570 \pm$ & $0.141^{\mathrm{aA}}$ & $5.760 \pm$ & $1.271^{\mathrm{bA}}$ & $7.200 \pm$ & $0.456^{\mathrm{abA}}$ & $7.177 \pm$ & 0.486 \\
\hline & Non-infected & $9.000 \pm$ & $0.258^{\mathrm{aB}}$ & $8.600 \pm$ & $0.267^{\mathrm{aB}}$ & $8.600 \pm$ & $0.267^{\mathrm{aA}}$ & $8.733 \pm$ & 0.151 \\
\hline \multirow{2}{*}{ Heterophils(\%) } & E. coli infected & $55.340 \pm$ & $1.990^{\mathrm{aA}}$ & $58.351 \pm$ & $4.945^{\mathrm{aA}}$ & $65.810 \pm$ & $2.198^{\mathrm{bA}}$ & $59.834 \pm$ & 2.026 \\
\hline & Non-infected & $33.100 \pm$ & $0.690^{\mathrm{aB}}$ & $33.200 \pm$ & $0.696^{\mathrm{aB}}$ & $33.000 \pm$ & $0.775^{\mathrm{aB}}$ & $33.100 \pm$ & 0.402 \\
\hline \multirow[t]{2}{*}{ Eosinohils(\%) } & E. coli infected & $14.960 \pm$ & $1.423^{\mathrm{aA}}$ & $13.999 \pm$ & $2.881^{\mathrm{aA}}$ & $8.080 \pm$ & $1.393^{\mathrm{bA}}$ & $12.346 \pm$ & 1.260 \\
\hline & Non-infected & $4.500 \pm$ & $0.342^{\mathrm{aB}}$ & $3.600 \pm$ & $0.499^{\mathrm{aB}}$ & $3.600 \pm$ & $0.476^{\mathrm{aA}}$ & $3.900 \pm$ & 0.260 \\
\hline \multirow[t]{2}{*}{ Basophils (\%) } & E. coli infected & $0.450 \pm$ & $0.093^{\mathrm{aA}}$ & $0.320 \pm$ & $0.081^{\mathrm{aA}}$ & $0.290 \pm$ & $0.072^{\mathrm{aA}}$ & $0.353 \pm$ & 0.048 \\
\hline & Non-infected & $0.240 \pm$ & $0.031^{\mathrm{aA}}$ & $0.340 \pm$ & $0.052^{\mathrm{aA}}$ & $0.380 \pm$ & $0.051^{\mathrm{aA}}$ & $0.320 \pm$ & 0.028 \\
\hline
\end{tabular}

not differ significantly $(\mathrm{P} \leq \mathbf{0 . 0 5})$ 
Table.2 Serum biochemical alterations in broiler chicken spontaneously affected with colibacillosis

\begin{tabular}{|c|c|c|c|c|c|c|c|c|c|}
\hline \multirow{2}{*}{$\begin{array}{l}\text { Parameters } \\
\text { AST (U/L) }\end{array}$} & \multirow{2}{*}{$\begin{array}{l}\text { Group } \\
\text { Infected }\end{array}$} & \multicolumn{2}{|l|}{ 8-14 days } & \multicolumn{2}{|l|}{ 15-21 days } & \multicolumn{2}{|c|}{ 22-28 days } & \multicolumn{2}{|l|}{ Total } \\
\hline & & $96.2820 \pm$ & $6.46716^{\mathrm{abA}}$ & $105.8330 \pm$ & $9.32181^{\mathrm{aA}}$ & $89.9770 \pm$ & $2.93146^{\mathrm{bA}}$ & $97.3640 \pm$ & $3.95853^{\mathrm{A}}$ \\
\hline & Non-infected & $56.3230 \pm$ & $1.22802^{\mathrm{aB}}$ & $57.4300 \pm$ & $1.59827^{\mathrm{aB}}$ & $57.0400 \pm$ & $1.43389^{\mathrm{aB}}$ & $56.9310 \pm$ & $0.80013^{\mathrm{B}}$ \\
\hline \multirow[t]{2}{*}{ ALT (U/L) } & Infected & $84.2540 \pm$ & $2.49811^{\mathrm{aA}}$ & $83.1610 \pm$ & $2.37797^{\mathrm{aA}}$ & $87.8650 \pm$ & $3.19663^{\mathrm{aA}}$ & $85.0933 \pm$ & $1.55787^{\mathrm{A}}$ \\
\hline & Non-infected & $65.9900 \pm$ & $1.32811^{\mathrm{aB}}$ & $63.5700 \pm$ & $0.86101^{\mathrm{aB}}$ & $65.6900 \pm$ & $1.16566^{\mathrm{aB}}$ & $65.0833 \pm$ & $0.66312^{\mathrm{B}}$ \\
\hline \multirow{2}{*}{$\begin{array}{l}\text { Total Protein } \\
\text { (g/dL) }\end{array}$} & Infected & $5.2540 \pm$ & $0.04612^{\mathrm{aA}}$ & $5.5580 \pm$ & $0.08354^{\mathrm{bA}}$ & $5.4830 \pm$ & $0.05485^{\mathrm{bA}}$ & $5.4317 \pm$ & $0.04278^{\mathrm{A}}$ \\
\hline & Non-infected & $6.1730 \pm$ & $0.04614^{\mathrm{abB}}$ & $6.0500 \pm$ & $0.04534^{\mathrm{aB}}$ & $6.2400 \pm$ & $0.0718^{\mathrm{bB}}$ & $6.1543 \pm$ & $0.03435^{\mathrm{B}}$ \\
\hline \multirow{2}{*}{$\begin{array}{l}\text { Albumins } \\
\text { (g/dL) }\end{array}$} & Infected & $2.3070 \pm$ & $0.02271^{\mathrm{aA}}$ & $2.4290 \pm$ & $0.02527^{\mathrm{abA}}$ & $2.5240 \pm$ & $0.05550^{\mathrm{bA}}$ & $2.4200 \pm$ & $0.02665^{\mathrm{A}}$ \\
\hline & Non-infected & $3.4400 \pm$ & $0.07775^{\mathrm{aB}}$ & $3.4400 \pm$ & $0.06864^{\mathrm{aB}}$ & $3.4300 \pm$ & $0.04955^{\mathrm{aB}}$ & $3.4367 \pm$ & $0.03698^{\mathrm{B}}$ \\
\hline \multirow{2}{*}{$\begin{array}{l}\text { Globulins } \\
\text { (g/dL) }\end{array}$} & Infected & $2.9470 \pm$ & $0.04480^{\mathrm{aA}}$ & $3.1290 \pm$ & $0.09702^{\mathrm{aA}}$ & $2.9590 \pm$ & $0.04352^{\mathrm{aA}}$ & $3.0117 \pm$ & $0.04019^{\mathrm{A}}$ \\
\hline & Non-infected & $2.7330 \pm$ & $0.07674^{\mathrm{aA}}$ & $2.6100 \pm$ & $0.09481^{\mathrm{aB}}$ & $2.8100 \pm$ & $0.10483^{\mathrm{aA}}$ & $2.7177 \pm$ & $0.05394^{\mathrm{B}}$ \\
\hline
\end{tabular}

*Means bearing at least one common lowe case superscript between age groups and upper case superscript between groups for a particular parameter does not differ significantly $(\mathrm{P} \leq \mathbf{0 . 0 5})$ 
The increase in AST activity might be attributed to myocarditis as observed in Escherichia coli infected birds, since this enzyme is present in large quantities in cardiac muscles (Benjamin, 1978), where as the increase in ALT might be due to release of this enzyme from liver as a result of hepatitis. Since an increase in activity of serum ALT is considered to be a sensitive indicator of hepatic cell damage and alteration in permeability of hepatic cell membrane (Christen \& Metzler, 1985). The earlier reports also showed similar pattern of increase in AST and ALT levels in E. coli infected birds (Christie \& Haliday, (1979), Jindal et al., (2003), Koynarski et al.( 2010).

The overall mean total protein value in Escherichia coli infected chicken (5.431 \pm $0.042 \mathrm{~g} / \mathrm{dL})$ was significantly lower when compared with non infected chicken (6.154 \pm $0.034 \mathrm{~g} / \mathrm{dL}$ ). The mean values of total protein between age groups within the infected group varied significantly and were lower in 8-14 days of age when compared with other age groups. The overall mean albumin value in Escherichia coli infected chicken (2.420 \pm $0.026 \mathrm{~g} / \mathrm{dL}$ ) was significantly lower when compared with non infected chicken $(3.436 \pm$ $0.036 \mathrm{~g} / \mathrm{dL})$. The mean values of albumin between age groups within the infected group varied significantly and were lower in 8-14 days of age when compared with other age groups. The overall mean globulin value in Escherichia coli infected chicken (3.011 \pm 0.040 (g/dL) was significantly higher when compared with non infected chicken $(2.711 \pm$ $0.053(\mathrm{~g} / \mathrm{dL}))$. The mean values of globulin between age groups within the infected group did not vary significantly. The mean values for total protein and albumin were significantly decreased where as the values for globulins were significantly higher in Escherichia coli infected birds when compared with age matched birds of noninfected group. The decrease in total protein and albumin may be attributed to severe hepatic damage, found in colibacillosis. The results were in concurrence with the earlier reports of Jindal et al., (2003) who also observed significant decrease in values of total protein and albumin in Escherichia coli infected birds. The increase in globulin might be attributed to immune response of the birds against infection of E. coli. However, results were contrary to the reports of Jindal et al., (2003), who observed decrease in globulins in Escherichia coli infected birds.

From this study it was concluded that the Colibacillosis did not cause marked alteration in haematological indices. However, liver function tests were significantly altered.

\section{References}

Barnes HJ, Vaillancourt JP, and Gross WB. 2003. Colibacillosis. In Saif, Y. M. $\left(10^{\text {th }}\right.$ edition), Diseases of Poultry. Iowa Stat Press, Ames, IA, USA. pp. 631-656.

Barnes HN. (2008). Diseases of poultry. 12th ed. Blackwell Pub. Professional, Ames, Iowa. pp. 691-732.

Benjamin MM. 1978. Outline of veterinary clinical pathology, 3rd ed, Iowa State University press, USA. pp. 43-47.

Christen P, and Metzler DE. 1985. Transaminases. John Wiley and Sons, New York. pp. 307-362.

Christie G, and Halliday WG. 1979. Haematological and biochemical aspect of Escherichia coli septicaemia in brown leghorn chicken. Avian Pathology 81: 45-55.

Gangane GR, Kulkarni GB, and Yeotikar PV. 2006. Studies on experimental colibacillosis in chicks. Indian Veterinary Journal 83: 118-119.

Goswami P, Chakrabarti A, Hui AK, Das R, and Ray N. 2004. Isolation, identification and antibiogram of Escherichia coli from poultry in field 
conditions. Journal of Interacademia 81: 951-952.

Jain NC. 1986. Schalm's Veterinary Haematology, $4^{\text {th }}$ Edn. Lea and febiger, 600 Washington Square, Philadelphia, PA 19106-4198, USA.

Jalil H, and Das P. 2001. Biochemical and serological characterization of Escherichia coli from commercial poultry. Pakistan Journal of Animal Science Research 53: 10-14

Jindal N, Kumar A, Shukla CL, Pal Y, Ledoux DR, and Rottinghaus GE. 2003. Effect of ochratoxin A on Escherichia coli challenged broiler chicks. Avian Diseases 47: 415-424.

Koynarski V, Mircheva T, Stoev S, Urumova V, Zapryanova D, Dishlyanova E, Koynarski TS, and Karov RS. 2010. Pathoanatomical and blood biochemical investigations in chicks, challenged with Escherichia coli on the background of a pre-existing Eimeria infection. Revue Méd. Vét 161(3):133140.
Lutful Kabir SM. 2010. Avian Colibacillosis and Salmonellosis. A closer look at epidemiology, pathogenesis, diagnosis, control \& public health concern. International Journal of Environmental Health \& Public Health 7(1): 89-114.

Nandawar MB, Gangane GR, Moregaonkar SD, Kulkarni GB, and Degloorkar NK. 1999. Haematological changes in orally induced colibacillosis in chicks. National Symposium on Topic of current Interest in Pathology of Animal and Poultry Diseases. The Millenium Approach and XVI Annual Conference of Indian Association of Veterinary Pathologists, Bangalore, Nov 25-27, pp: 212.

Timothy JJ, Yvonne W, Curt D, Sara JJ, Sandra CR, and Lisa KN. 2008. Identification of Minimal Predictors of Avian Pathogenic Escherichia coli. Journal of Clinical Microbioiology 46: 3987-3996.

\section{How to cite this article:}

Umar Amin, S. A. Kamil, B. M. Wani, Saim Qureshi, S. A. Shah, Tanveer Ahmad Dar, S. Adil and Mir, M. S. 2020. Haematological and Biochemical Alterations of Broiler Chicken Affected Naturally with Colibacillosis. Int.J.Curr.Microbiol.App.Sci. 9(06): 1906-1913. doi: https://doi.org/10.20546/ijcmas.2020.906.236 